\title{
Research on business model innovation path
}

\author{
Ying Meng ${ }^{1, a}$, Xiaoyan Lai ${ }^{2, b}$ \\ ${ }^{1,2}$ Business School of Jiangxi Normal University,Nanchang330022,China \\ amengyingss@sohu.com, b995234630@qq.com
}

Keywords: business model; innovation path; marketing model; profit model

Abstract:Business model innovation is helpful for enterprises to gain competitive advantage, to create long-term economic profit, more and more enterprise management experts and scholars began to pay attention to and study business model innovation. How can we achieve the business model innovation, and ultimately achieve the growth of enterprise economic benefits? This paper from three aspects of commercial positioning, marketing model and profit model, discusses the innovation path of business model.

\section{Introduction}

Business model innovation is the key to gain the core competitiveness of enterprises. As Drucker said: "the competition among enterprises is not the competition between products, but the competition of business models." However, in today's information era, the macro and micro environment is rapidly changing, the rapid development of science and technology, the sustainable management and development of enterprises are facing great challenges, the original business model in a relatively stable stage, is facing a qualitative change.In this opportunity and challenge coexist situation, if the enterprise want to grasp the market opportunity, in the competition to remain invincible, we must continue to innovate the business model.

\section{The definition of business model innovation}

For business model innovation, the earliest dating back to the end of nineteenth Century, Rockefeller discovered the secrete of business model innovation on the the understanding of transaction costs, the production and business activities can be concentrated in the company to reduce transaction costs[1].Later, with the in-depth understanding of the business model, found that business model innovation is critical to the development of an enterprise, especially in today's fiercely competitive market, companies must explore the change or innovate of business model if they want to succeed.

Although business model innovation is very important, but it is not easy to innovate business model.First of all, business model innovation is not the innovation of product, it is invisible.Secondly, business model innovation is a relatively new concept, therefore, the discussion about the business model is lack of unity and accuracy, and there are many misunderstandings about it.Finally, to achieve business model innovation, entrepreneurs must have the ability to insight into the business environment changes, can effectively capture changes in the business environment for business model innovation opportunities, and to configure the various elements of an effective business model[2,3].But in fact, many entrepreneurs are lack of sufficient understanding of their own business model, not to mention innovation. 


\section{The business model innovation path}

A sustainable and profitable new business model should include both customer value and enterprise value two core content.Among them, the customer value is the value of the enterprise to provide customers.And the enterprise value is the value of their own, bring in the process of providing customers with value.

To further the customer value and enterprise value, we will get the three elements of a business model that is sustainable and profitable: business positioning, marketing model, profit model.Business model innovation is to change the business model, from the original business model to a truly innovative business model through transformation, the enterprise mainly through three paths to achieve business model innovation: first, business positioning innovation; second, marketing mode innovation; and third, profit model innovation[4].

\section{Business positioning innovation}

The most critical of the enterprise is to find customers,through helping customers solve problems, or to provide a good experience to earn income and revenue, and therefore commercial location consists of three parts: the target consumer,that is, we sell to who, value proposition, we sell what products; product differentiation, our products and other similar products have any differences. From these three angles, the innovation of commercial positioning can be realized.

First of all, it is the innovation of the target consumer group.Changes in the sales target generally require companies to re select a category of consumers, the consumer may be previously ignored by the enterprise, or not focused,or the new technology to meet the new potential consumers, because companies do not have targeted sales, potential customers do not know the value of enterprise products and services.

Secondly, it is the innovation of value proposition.Product or service value proposition innovation usually brings product innovation, specific practices include: first, the use of new technologies to launch new products or increase the new service to better meet the requirements of customers; the second is based on the existing conventional functional characteristics, adding new features to the existing products to better serve the specific target groups[5]. Many times the target consumers and the change of the value proposition is synchronous, namely both have changed, which makes the enterprise to strengthen the value proposition for the target consumers.

\section{Marketing mode innovation}

Throughout the two years of the Internet industry, which in addition to give consumers more autonomy, bringing a change in consumer habits, but also directly prompted a shift in corporate marketing model.With the consumer becoming the value core of the new marketing concept, models upgrade issues which enterprises facing has become essential.

Experiential marketing is a kind of marketing method, which makes the customer experience the product or service provided by the enterprise, so that the customer can perceive the product or service quality or performance. The goal of this approach is to meet the needs of the consumer experience,service products as the platform, with tangible products as the carrier, production, management of high quality products, to narrow the distance between enterprises and consumers.

Enterprises in the implementation of experiential marketing should pay attention to the following two principles: first, appropriate.Experiential marketing requires products and services have certain experience characteristics,customers who in order to obtain the "experience feeling"during the purchase and consumption process,often hesitate to spend more costs.Second, reasonable and legitimate. Whether experiential marketing can be accepted by consumers, and it has a close relationship with the regional difference. In different countries and regions due to the different customs and culture, value concept and value evaluation criteria are different, so the 
results of evaluation are different.Therefore, experience marketing activities, must adapt to the local market, local customs and practices, both innovative, and comply with common sense.

The new concept of fans thinking is very hot in the last two years,as long as there are fans, there will be a reputation.Fans have a lot of advantages, for the enterprise, the biggest advantage is blindness, the blind love of product ,tolerance and even turn a blind eye to the problem, they can not stop buying products from generation to generation, will continue to take the initiative to recommend to others[6].So you will find that a lot of not so good souvenir, but sold well, in other words, the fans in the traditional sense do not care about product quality, but pay more attention to feel participation.So our brand needs fans, they are the best target consumers, Not only do they have a high degree of loyalty and enthusiasm to your brand, your company, but also to spread your reputation in his social circle to help you get a nonlinear growth or even explosive growth.

\section{profit model innovation}

The ultimate goal of enterprise management is to obtain the profit, so that enterprises can continue to survive and develop. Therefore, enterprises must innovate the profit model to expand revenue.

First, Split value chain to profit.Now a lot of enterprises have realized that stick to the integration of upstream and downstream, production and supply and marketing of a dragon strategy has been out of date, for many industries, it is not possible to be competitive in all aspects, Mature enterprises should find the key position of the value chain, and to build strategic control points, relying on their own ability to shape the key aspects of control ability.

Second, to the brand effective extension to profit.After the existing brand profit to reach a certain scale, the enterprise can also be effectively extended to other categories, to further expand the profit space[7].

An extension is to play the influence of the existing brand, the brand will play to the maximum effectiveness, the use of "strong brand influence" to carry out the relevant industry development and related products manufacturing. Such as Master Kong after becoming the first brand of instant noodles, and then expand its business to drinks, biscuits and other areas, and other areas of business in the "Master Kong" strong brand halo developed rapidly.This is the "brand effect" as the driving, the development of the related industries to obtain a huge profit of the brand extension mode.

Another extension is through the sub brand strategy, the use of existing channels, distribution network and market experience to create a sub brand, to expand the user groups, to obtain profit space.Xizhilang enterprise is through the effective brand extension into solid milk market and successful launch the product of Youlemei.And through the concept and demands of lovers,carry out interactive marketing for 15 -25 years old young fashion group,make youlemei became the synonymy of milky tea ,thus further enrich the Xizhilang sub brand, successfully enter more food field, expand the scope of profit.

\section{Conclusions}

The market environment is changing rapidly, the market competition is increasingly fierce,the intimation of successful business model bring convergence, so that no business model is static, business model innovation will always be the focus of attention of the enterprise, the purpose of the enterprise management is to obtain profits, therefore, enterprise business model innovation should take the customer as the center, to adjust and optimize the allocation of various resources, to create a variety of contacts with the concept of win-win cooperation, and constantly thinking of their own business model, from three angles of business orientation, marketing mode and profit model, adopt 
appropriate innovative ways to adjust the business model, in order to obtain sustainable competitive advantage.

\section{Acknowledgments}

This work was financially supported by the special fund for the development plan of the young teachers in the ordinary universities of Jiangxi province.

\section{References}

[1] Kun Shi. Market Structure And Business Model Innovation Path Selection [J]. Jiangsu business theory, 2015,03:11-13.(In Chinese)

[2] Yongbo Sun,Liuqin Chen. Dynamic mechanism of business model innovation and its path selection[J].Development research, 2011,11:78-85.(In Chinese)

[3] Jizheng Ma. Implementation of Business Mode Innovation and Its Evolution-Based on Value Chain[J]. Ning Bo Economy, Reform and strategy, 2015,07:57-60.(In Chinese)

[4] Min Luo, Liangyu Li. The Innovation of Business Model in Internet Era: From Value Creation Perspective[J]. China Industrial Economics, 2015,01:95-107.(In Chinese)

[5] Changyun Li. Innovations of Business Model Caused by the Next Generation of Information Technology [J]. China soft science, 2012,04:167-176.(In Chinese)

[6] Chun Li, Lili Gao. Analysis of the basic path of business model innovation [J]. contemporary economy, 2010,12:46-47.(In Chinese)

[7] Tingting Wang. Construction of China's transaction banking business model path [J]. South are altar, 2016, 03: 114-118. 